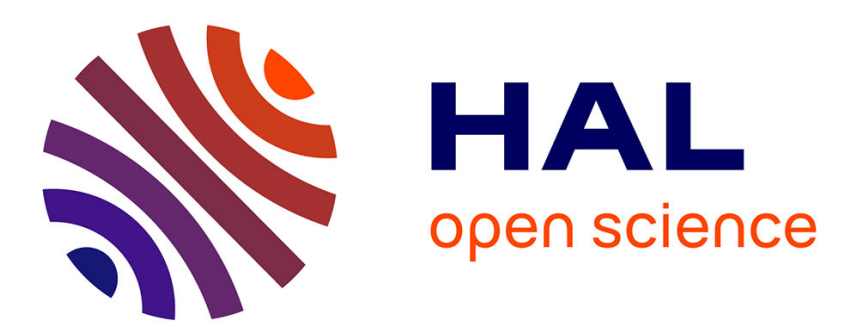

\title{
Utilization of bio-based glycolaldehyde aqueous solution in organic synthesis: application to the synthesis of 2,3-dihydrofurans
}

Jing Xu, Wenbo Huang, Rongxiang Bai, Yves Queneau, François Jerome, Yanlong $\mathrm{Gu}$

\section{To cite this version:}

Jing Xu, Wenbo Huang, Rongxiang Bai, Yves Queneau, François Jerome, et al.. Utilization of bio-based glycolaldehyde aqueous solution in organic synthesis: application to the synthesis of 2,3dihydrofurans. Green Chemistry, 2019, 21 (8), pp.2061-2069. 10.1039/C8GC04000A . hal-02884791

\section{HAL Id: hal-02884791 \\ https://hal-udl.archives-ouvertes.fr/hal-02884791}

Submitted on 8 Jul 2020

HAL is a multi-disciplinary open access archive for the deposit and dissemination of scientific research documents, whether they are published or not. The documents may come from teaching and research institutions in France or abroad, or from public or private research centers.
L'archive ouverte pluridisciplinaire HAL, est destinée au dépôt et à la diffusion de documents scientifiques de niveau recherche, publiés ou non, émanant des établissements d'enseignement et de recherche français ou étrangers, des laboratoires publics ou privés. 


\section{Utilization of bio-based glycolaldehyde aqueous solution in organic synthesis: application to the synthesis of 2,3-dihydrofurans}

Jing Xu, ${ }^{\mathrm{a}}$ Wenbo Huang, ${ }^{\mathrm{a}}$ Rongxian Bai, ${ }^{\mathrm{a}}$ Yves Queneau, ${ }^{\mathrm{d}}$ Francois Jerome ${ }^{* \mathrm{c}}$ and and Yanlong $\mathrm{Gu}^{* a, b}$

a. Key Laboratory of Energy Conversion and Storage, Ministry of Education, School of Chemistry and Chemical Engineering, Huazhong University of Science and Technology, Wuhan 430074, China. E-mail: klgyl@ hust.edu.cn

b. State Key Laboratory for Oxo Synthesis and Selective Oxidation, Lanzhou Institute of Chemical Physics, 730000, Lanzhou, China.

c. Institut de Chimie des Milieux et Matériaux de Poitiers, Ins Université de Poitiers, ENSIP, 1 rue Marcel Dore, 86073 Poitiers cedex 9, France. E-mail: francois.jerome@ univ-poitiers.fr

d. Institut de Chimie et Biochimie Moléculaires et Supramoléculaires (ICBMS), Université de Lyon, CNRS, Université Lyon 1, INSA Lyon, CPE Lyon, UMR 5246, Université Claude Bernard, Bâtiment Lederer, 1 Rue Victor Grignard, 69622 Villeurbanne, France.

\footnotetext{
Abstract. Glycolaldehyde is a biomass-derived chemical compound available from cellulose or glucose. Until now, little attention has been devoted to its use towards value-added chemicals. To explore novel transformations of glycolaldehyde, in this work, a threecomponent reaction of glycolaldehyde, indole and 1,3-dicarbonyl compound was developed to synthesize a class of 3-(indol-3-yl)-2,3-dihydrofurans. Using glycolaldehyde diethyl acetal as glycolaldehyde source, the reaction can be performed in organic solvents, and two catalytic systems were proved to be effective: (a) $\mathrm{Sc}(\mathrm{OTf})_{3} /$ nitromethane; and (b) $\mathrm{Ni}\left(\mathrm{ClO}_{4}\right)_{2} \cdot 6 \mathrm{H}_{2} \mathrm{O} /$ acetonitrile. However, these conditions applied to the direct use of the biobased glycolaldehyde aqueous solution did not provide the dihydrofurans efficiently. To enable the use of the aqueous solution of glycolaldehyde, a hitherto unreported deep eutectic solvent (DES) was developed by using $\mathrm{FeCl}_{3} \cdot 6 \mathrm{H}_{2} \mathrm{O}$ and meglumine ( $N$-methylglucamine) as precursors. The $\mathrm{FeCl}_{3} 6 \mathrm{H}_{2} \mathrm{O} /$ meglumine DES was characterized by FTIR, TGA and DSC, and the obtained results demonstrated unambiguously the formation of a DES. This DES was found to be an efficient and a water-compatible promoting medium for the above mentioned three-component
} 
reaction. A variety of 3-(indol-3-yl)-2,3-dihydrofuranfurans were synthesized in good yields. The $\mathrm{FeCl}_{3} \cdot 6 \mathrm{H}_{2} \mathrm{O} /$ meglumine DES system can also be recycled without significant loss of activity.

\section{Introduction}

In consideration of environmental issues and economic stress, biomass conversion has become more attractive because energy, fuels and chemicals/materials can be co-produced in the process called biorefinery. Therefore, strategies and processes devoted to the conversion of biomass have been the focus of intense research by chemists recently. ${ }^{1}$ However, most of the biomass conversion reactions involve the formation of water. For example, pyrolysis oil derived from biomass contains $15-25 \mathrm{wt} \%$ water. ${ }^{2}$ In some cases, the amount of water is so significant that it can affect notably the quality of the main product. Glycolaldehyde is one of the valuable biomass-derived platform molecules, and it can be produced by hydrolysis of cellulose or glucose followed by a selective retro-aldol condensation. ${ }^{3}$ Nowadays, glycolaldehyde is mostly used as food browning agent. ${ }^{4}$ It was also proved to be an intermediate in the formation of ethylene glycol or ethanolamine from glucose or cellulose. ${ }^{5}$ Because of its unique reactivity, bio-based glycolaldehyde exhibits a great potential to be used in the synthesis of fine chemicals. However, owing to the difficulty of removing water in the bio-sourced product, it is necessary to consider using directly the aqueous solution of glycolaldehyde in the downstream valueadded transformations. ${ }^{6}$ In this context, water-compatible catalytic systems and watercompatible media, such as DES, should be the best choices.

DESs (deep eutectic solvents) are generally composed of two or three cheap and safe compounds. Intermolecular interaction of all the components lead to the formation of deep eutectic mixtures with one melting point lower than that of each individual component. Most of present widely-used DESs is choline chloride $(\mathrm{ChCl})$-based DESs. ${ }^{7}$ It is a cheap and biodegradable quaternary ammonium salt which can be extracted from biomass. In combination with hydrogen bond donors such as carboxylic acid, polyols/sugars and amides, $\mathrm{ChCl}$ is liable for rapidly forming a DES. The physico-chemical properties and applications of these DESs in some areas, such as dissolution, extraction process, electrochemistry and material chemistry, have been extensively explored. ${ }^{8}$ And several DESs formed by zinc chloride are reported. These DESs are acidic, can thus be applied in organic synthesis as dual solvents/catalysts, for example, in the synthesis of alkylation and acylation of arenes. ${ }^{9}$ Recently, some metal halides-based DESs have been reported and employed in organic catalysis. However, little attention has been devoted to the design of specific-target DESs. Therefore, we focus more on designing a 
specific-target DESs in novel organic synthesis. The use of DESs in organic reactions not only ensures good synthesis efficiency but also endows the reaction system with green chemistry credential. Therefore, DESs have already become a preferable choice of chemists to develop green and sustainable chemical transformations. ${ }^{10}$

Among possible targets are the very interesting five-membered furan and dihydrofuran rings which can be found in a fascinating array of bioactive natural products and pharmaceutical compounds. ${ }^{11}$ Therefore, efficient synthesis of these derivatives is of high interest and consequently many procedures have been developed. ${ }^{12}$ We have paid much attention to the ring embellishment and transformations of furan or dihydrofuran derivatives in the past decade. ${ }^{13}$ Particularly, by combining a bifunctional aldehyde and a nucleophilic indole together, some interesting approaches to heterocyclic derivatives can be achieved. ${ }^{14}$ Glycolaldehyde being a bifunctional nucleophilic and electrophilic species, it can therefore be possibly used as precursor for synthesizing some five-membered dihydrofurans. Considering also the bio-based origin of glycolaldehyde, if a new synthesis reaction forming a specific class of heterocycles were established, it would provide suitable routes and options for value-added transformation of biomass. Hence, we focused our effort on this topic by investigating the direct use of glycolaldehyde aqueous solution towards furans and we report herein our preliminary results obtained in this endeavor.

\section{Results and discussion}

Initially, commercially available glycolaldehyde acetal was used as an alternative reagent to glycolaldehyde in the beginning of this study. Under acidic conditions, glycolaldehyde can be released via deacetalization reaction. ${ }^{15}$ Initially, a mixture of glycolaldehyde diethyl acetal 1a, ethyl acetoacetate 2a and indole 3a was treated under the conditions tabulated in Table 1 . Theoretically speaking, the molar ratio of $1 \mathbf{a} / \mathbf{2 a} / \mathbf{3 a}$ was $1 / 1 / 1$ for the synthesis of the target dihydrofuran 4a. Taking into account that a byproduct, ethyl 2-methyl-3-furancarboxylate 5a, might be formed through a reaction of $\mathbf{1 a}$ and $\mathbf{2 a},{ }^{16}$ and the molar ratio of $\mathbf{1 a} / \mathbf{2 a} / \mathbf{3 a}$ was temporarily fixed at $2 / 2 / 1$ with the aim of obtaining higher $\mathbf{4 a}$ yields.

In the absence of catalyst, no reaction occurred after $1 \mathrm{~h}$ of reaction at $80{ }^{\circ} \mathrm{C}$ in acetonitrile or nitromethane (Table 1, entry 1). When $\operatorname{Sc}(\mathrm{OTf})_{3}$ was used as catalyst in conjunction with using nitromethane as solvent, 3a consumed rapidly at room temperature, and $\mathbf{4 a}$ was isolated in $81 \%$ yield after $1 \mathrm{~h}$ of reaction (entry 2$)$. Al(OTf) 3 
and $\mathrm{Fe}(\mathrm{OTf})_{3}$ were also able to catalyze this reaction, but the yields of $\mathbf{4 a}$ were inferior as compared with $\mathrm{Sc}(\mathrm{OTf})_{3}$ (entries 3 and 4). The formation of a by-product $\mathbf{5 a}$ could be clearly observed in these cases, which was partially responsible for the insufficient synthesis of 4a. When $\mathrm{Ni}(\mathrm{OTf})_{2}$ and $\mathrm{Ni}\left(\mathrm{ClO}_{4}\right)_{2} \cdot 6 \mathrm{H}_{2} \mathrm{O}$ were used, only unreacted starting materials were recovered (entry 5). A strong Brønsted acid, p-toluenesulfonic acid $(\mathrm{TsOH})$, was also examined under the identical conditions, but no product can be detected (entry 6). Then, the effect of solvent was explored. Among all the solvents screened, nitromethane clearly stood out with acetonitrile in a near second place (entries 2 and 7). The reaction proceeded sluggishly in 1,2-dichloroethane and toluene, producing 4a only in moderate yields (entries 8 and 9). Ethanol was proven to be inappropriate for this reaction (entry 10).

Although the target dihydrofuran $\mathbf{4 a}$ can be synthesized in good yield, owing to the use of nitromethane, which is a toxic and an explosive solvent, ${ }^{17}$ the greenness of $\mathrm{Sc}(\mathrm{OTf})_{3} /$ nitromethane system is thus far from satisfactory. The significant solvent effect observed over $\mathrm{Sc}(\mathrm{OTf})_{3}$ catalyst led us to scrutinize the catalytic activities of some other acids in different solvent systems. From the viewpoint of industrial uses, acetonitrile is much better than nitromethane although it is still toxic. This can be witnessed by the wide uses of acetonitrile in pharmaceutical synthesis. ${ }^{18} \mathrm{We}$ therefore paid our attention particularly to acetonitrile. It was found that, by using $\mathrm{Ni}\left(\mathrm{ClO}_{4}\right)_{2} \cdot 6 \mathrm{H}_{2} \mathrm{O}$ as catalyst $(20 \mathrm{~mol} \%)$, the reaction proceeded very well at $80{ }^{\circ} \mathrm{C}$. And $4 \mathbf{a}$ could be obtained in $79 \%$ yield after $6 \mathrm{~h}$ of reaction (entry 11). But, the formation of $5 \mathbf{a}$ was unavoidable. The reaction over $\mathrm{Ni}(\mathrm{OTf})_{2}$ catalyst proceeded also smoothly. However, perhaps due to the easy formation of $\mathbf{5 a}$, the yield of $\mathbf{4 a}$ reached only $61 \%$ (entry 12 ). For the reaction over $\mathrm{Ni}\left(\mathrm{ClO}_{4}\right)_{2} \cdot 6 \mathrm{H}_{2} \mathrm{O}$ catalyst, solvent effect is also significant, which can be verified by the results obtained with toluene and ethanol, and those are inappropriate for this reaction (entries 13 to 15). At this stage of our study, two systems were identified to be suitable to implement the synthesis of 4a: (A) $\operatorname{Sc}(\mathrm{OTf})_{3}$ (5 mol\%)/nitromethane, with this system, the reaction can be performed at room temperature, and finished within $1 \mathrm{~h}$; and $(\mathbf{B}) \mathrm{Ni}\left(\mathrm{ClO}_{4}\right)_{2} \cdot 6 \mathrm{H}_{2} \mathrm{O}(20 \mathrm{~mol} \%) /$ acetonitrile, with this system, the reaction has been performed at $80^{\circ} \mathrm{C}$, and $6 \mathrm{~h}$ are needed to get a good reaction yield (optimization of the reaction parameters, such as temperature and reaction time, is given in SI, Table $\mathbf{S 1}$ ).

The effect of catalyst amount on the model reaction was then investigated. As shown in Figure 1, the performance of the model reaction was influenced quite notably by the 
amount of $\mathrm{Sc}(\mathrm{OTf})_{3}$ or $\mathrm{Ni}\left(\mathrm{ClO}_{4}\right)_{2} \cdot 6 \mathrm{H}_{2} \mathrm{O}$. Increasing the concentration of these acid catalysts in general led to improvement of the reaction yield. For $\operatorname{Sc}(\mathrm{OTf})_{3} /$ nitromethane system, this tendency is quite obvious when the amount of $\operatorname{Sc}(\mathrm{OTf})_{3}$ is lower than 2.0 mol\% (Figure 1, a). While the yield of $\mathbf{4 a}$ can be improved from $15 \%$ to $67 \%$ by increasing the loading of $\mathrm{Sc}(\mathrm{OTf})_{3}$ catalyst from $0.5 \mathrm{~mol} \%$ to $2.0 \mathrm{~mol} \%$, an increase of the scandium loading from 2.0 mol\% to 5.0 mol\% gained only $14 \%$ of yield increase. Taking together with the mild conditions and the short reaction time $(1 \mathrm{~h})$ of the method A, these results imply that the catalytic activity of $\mathrm{Sc}(\mathrm{OTf})_{3}$ is quite high, and a small amount of $\mathrm{Sc}(\mathrm{OTf})_{3}$ is sufficient enough to initiate the reaction. Indeed, when $0.5 \mathrm{~mol} \%$ of $\mathrm{Sc}(\mathrm{OTf})_{3}$ was used, the yield of $\mathbf{4 a}$ can be improved to the same level by elongating the reaction time to $12 \mathrm{~h}$ (See SI, Table S2). This was because small reaction rate than deactivation of catalyst. In method $\mathrm{B}$, with $\mathrm{Ni}\left(\mathrm{ClO}_{4}\right)_{2} \cdot 6 \mathrm{H}_{2} \mathrm{O}$ catalyst/acetonitrile system, $5.0 \mathrm{~mol} \%$ of catalyst is sufficient enough to provide over $60 \%$ of yield under the standard conditions. Different from method A, the yield cannot be improved further by simply elongating the reaction (See SI, Table S2). Changing of the catalyst amount from 5.0 mol\% to $20.0 \mathrm{~mol} \%$ led to only $17 \%$ of yield increase.

Given that bio-based glycolaldehyde is generally produced in water, and is rather difficult to obtain in an anhydrous form with a high degree of purity, a water-compatible system should be preferable for updating bio-based glycolaldehyde to value-added products. To this end, we then investigated the effect of water to methods $\mathbf{A}$ and $\mathbf{B}$ for the synthesis of $\mathbf{4 a}$. As evidenced by the results in Figure 2, in a reaction in $0.2 \mathrm{mmol}$ scale, addition of water resulted in dramatic decrease of the reaction yield. Sc(OTf) 3 /nitromethane seems more sensitive toward water than $\mathrm{Ni}\left(\mathrm{ClO}_{4}\right)_{2} \cdot 6 \mathrm{H}_{2} \mathrm{O} /$ acetonitrile. It is reasonable considering the fact that a small amount of water has already induced into the reaction system as the hydrate of the $\mathrm{Ni}$ (II) salt in method $\mathbf{B}$. It should be mentioned that water is immiscible with nitromethane, and as a result, a biphasic system can be formed after adding some amounts of water with method $\mathbf{A}$ (the left picture in Figure 2). But, the reaction with method $\mathbf{B}$ is still a homogeneous system (the right picture in Figure 2). Whatever happens, after adding $7 \mathrm{mmol}(0.13 \mathrm{~g})$ of water into the reaction system, the yield of $\mathbf{4 a}$ sharply reduced to $<20 \%$. These results imply that methods $\mathbf{A}$ and $\mathbf{B}$ are both unable to implement the synthesis of $\mathbf{4 a}$ by using an aqueous solution of bio-based glycolaldehyde as precursor. Therefore, a water-compatible catalytic system that enables the use of bio-based glycolaldehyde is still appealingly needed.

On the other hand, DESs have gained much attention in the past decade. ${ }^{19}$ Like ionic liquids, DESs are generally less-volatile and their properties can be finely tuned by 
changing the component structures and the ratio of different components. But they have notable advantages, such as easy preparation, low cost and good recyclability. Therefore, DESs have been widely used as eco-friendly and sustainable alternatives to the conventional organic solvents in synthetic chemistry. Some of DESs can be synthesized by using metal halides as hydrogen bond acceptors (HBAs) in conjunction with the uses of amides, carboxylic acids or polyols as hydrogen bond donors (HBDs). ${ }^{20}$ This class of DESs are acidic, can thus be applied in organic synthesis as dual solvents/catalysts. We conjectured that acidic DESs might be suitable promoting media for aforementioned three-component reaction with high efficiency. To verify our hypothesis, a novel deep eutectic solvent (DES) was synthesized from $\mathrm{FeCl}_{3} \cdot 6 \mathrm{H}_{2} \mathrm{O}$ and meglumine at a molar ratio of $1: 2$ at $60{ }^{\circ} \mathrm{C}$ until a homogeneous liquid was obtained. ${ }^{21}$

The thereby obtained the DES was characterized by Fourier Transform Infrared (FTIR) spectroscopy (Figure 3A). The FTIR spectra of both DES and their two precursors $\left(\mathrm{FeCl}_{3} \cdot 6 \mathrm{H}_{2} \mathrm{O}\right.$ and meglumine) were recorded and put together in order for us to find any changes. The bottom blue line is for DES, the top black line is for $\mathrm{FeCl}_{3} \cdot 6 \mathrm{H}_{2} \mathrm{O}$, and the meddle red line is for meglumine. The peaks at about $2950 \mathrm{~cm}^{-1}$, $2850 \mathrm{~cm}^{-1}$ and $1450 \mathrm{~cm}^{-1}$ can be ascribed to $\mathrm{C}-\mathrm{H}$ symmetric stretching, $\mathrm{C}-\mathrm{H}$ asymmetric stretching and the $\mathrm{CH}_{2}$ bending vibration, respectively. ${ }^{22}$ The peaks at about $3327 \mathrm{~cm}^{-1}$ and $3239 \mathrm{~cm}^{-1}$ can be assigned to stretching vibration of $\mathrm{N}-\mathrm{H}$ band and $\mathrm{O}-\mathrm{H}$ bond of meglumine. ${ }^{23}$ An intermolecular interaction between $\mathrm{FeCl}_{3} \cdot 6 \mathrm{H}_{2} \mathrm{O}$ and meglumine can be verified by the broaden peaks at around these areas. And the peaks at about $1087 \mathrm{~cm}^{-1}$ and $1054 \mathrm{~cm}^{-1}$ can be assigned to $\mathrm{C}-\mathrm{O}$ stretching vibration of meglumine. In $\mathrm{FeCl}_{3} \cdot 6 \mathrm{H}_{2} \mathrm{O} /$ meglumine system, a slight red shift occurred, and the peaks appeared at $1078 \mathrm{~cm}^{-1}$ and $1038 \mathrm{~cm}^{-1}$, respectively. This result suggested that the DES are indeed formed by the coordination between $\mathrm{FeCl}_{3} \cdot 6 \mathrm{H}_{2} \mathrm{O}$ and meglumine. Moreover, at a loading below $50 \mathrm{wt} \%$, the amount of water has no significant effect on the formation of DES (see SI, Figure S1).

Thermal stability of the DES was investigated by TGA analysis, and the results are depicted in Figure 3B. Under mild conditions, a temperature ranging from $25{ }^{\circ} \mathrm{C}$ to 80 ${ }^{\circ} \mathrm{C}$, the weight of $\mathrm{FeCl}_{3} \cdot 6 \mathrm{H}_{2} \mathrm{O} /$ meglumine DES keeps nearly unchanged. The weight loss from $80{ }^{\circ} \mathrm{C}$ to about $200{ }^{\circ} \mathrm{C}$ can be ascribed to the evaporation of moisture and the decomposition of crystal water in $\mathrm{FeCl}_{3} \cdot 6 \mathrm{H}_{2} \mathrm{O} \cdot{ }^{24}$ The weight loss from $200{ }^{\circ} \mathrm{C}$ to about $330{ }^{\circ} \mathrm{C}$ can be linked to the decomposition of meglumine as meglumine starts to decompose about $200{ }^{\circ} \mathrm{C} .{ }^{25}$ The obtained TGA data indicated that 
$\mathrm{FeCl}_{3} \cdot 6 \mathrm{H}_{2} \mathrm{O} /$ meglumine DES has a quite good thermal stability under mild conditions (< $80{ }^{\circ} \mathrm{C}$ ), and can thus be applied as solvent or catalyst in a reaction. The differential scanning calorimeter (DSC) was used to investigate the thermal behavior of $\mathrm{FeCl}_{3} \cdot 6 \mathrm{H}_{2} \mathrm{O} /$ meglumine DES, and the DSC curves from $-60{ }^{\circ} \mathrm{C}$ to $0{ }^{\circ} \mathrm{C}$ are given in Figure 3C. Only one endothermic peak or exothermic peak in DSC curve can be observed and they are located in nearly the same temperature range. It may be connected with higher rates of relaxation of the structure of DES from liquid to grass state while cooling. ${ }^{26}$ This result indicated that no phase change appeared and only a glass transition temperature was observed at about $-30{ }^{\circ} \mathrm{C}$ for $\mathrm{FeCl}_{3} \cdot 6 \mathrm{H}_{2} \mathrm{O} /$ meglumine DES.

We then used the DES in the three-component reaction of indole, glycolaldehyde diethyl acetal and ethyl acetoacetate as dual solvents/catalysts. Some well-known DESs were also examined. In order to check the water compatibility of the newly developed DES catalytic system, water was also added (50 wt\% with respected to the weight of DES). The reaction was performed at $60{ }^{\circ} \mathrm{C}$ in the presence of $5 \mathrm{~mol} \%$ of DES-water mixtures. The obtained results were tabulated in Table 2. No reaction occurred when $\mathrm{ChCl} /$ ethylene glycol (1:2)- $\mathrm{H}_{2} \mathrm{O}$ was used (entry 1 ). This is quite reasonable as $\mathrm{ChCl} /$ ethylene glycol DES was known as a neutral DES. ${ }^{27}$ When $\mathrm{ZnCl}_{2} /$ ethylene glycol (1:2)- $\mathrm{H}_{2} \mathrm{O}$ was used, $4 \mathbf{a}$ can be isolated in $14 \%$ yield (entry 2). The reaction with $\mathrm{FeCl}_{3} \cdot 6 \mathrm{H}_{2} \mathrm{O} /$ ethylene glycol (1:2)- $\mathrm{H}_{2} \mathrm{O}$ gave nearly the same result (entry 3 ). In these DESs-mediated reactions, the formation of $\mathbf{5 a}$ can be clearly observed. A significant yield improvement was observed by changing the HBD component from ethylene glycol to glycerol. The reaction with $\mathrm{FeCl}_{3} \cdot 6 \mathrm{H}_{2} \mathrm{O} /$ glycerol (1:2)- $\mathrm{H}_{2} \mathrm{O}$ gave the desired $4 \mathbf{a}$ in $43 \%$ yield (entry 4). The side reaction toward the formation of $\mathbf{5 a}$ was also improved, but not as much as the $\mathbf{4 a}$-forming reaction. A novel DES-water mixture, $\mathrm{FeCl}_{3} \cdot 6 \mathrm{H}_{2} \mathrm{O} /$ meglumine (1:2)- $\mathrm{H}_{2} \mathrm{O}$, can also promote the reaction efficiently, and a fairly good yield of $4 \mathbf{a}, 46 \%$, can be obtained (entry 5). In order to further improve the reaction yield, we tried to increase the loading of $\mathrm{FeCl}_{3} \cdot 6 \mathrm{H}_{2} \mathrm{O} /$ meglumine (1:2)- $\mathrm{H}_{2} \mathrm{O}$. When it was used in $15 \mathrm{~mol} \%$, the yield of $\mathbf{4 a}$ can be improved to $63 \%$ (entry 6). By performing the reaction at $80{ }^{\circ} \mathrm{C}$, a yield up to $73 \%$ can be achieved (entry 7 ). In these cases, the formation of by-product 5a proceeded also inevitably. Fortunately, this side reaction consumed only a small part of substrate, thus the $\mathbf{4 a}$-forming reaction remains to be predominant. The molar ratio of HBA/HBD is also an important parameter to determine the catalytic activity of $\mathrm{FeCl}_{3} \cdot 6 \mathrm{H}_{2} \mathrm{O} / \mathrm{meglumine}-\mathrm{H}_{2} \mathrm{O}$. The optimal molar ratio of $\mathrm{FeCl}_{3} \cdot 6 \mathrm{H}_{2} \mathrm{O} /$ meglumine was proved to be $1: 2$ (entries 7, 8 and 9). To further identify 
whether the DES structure had a real role in the catalysis, we tested $\mathrm{FeCl}_{3} \cdot 6 \mathrm{H}_{2} \mathrm{O}$ in the reaction. When $15 \mathrm{~mol} \% \mathrm{FeCl}_{3} \cdot 6 \mathrm{H}_{2} \mathrm{O}$ was directly used, no desired product could be obtained after $10 \mathrm{~h}$ of reaction at $80^{\circ} \mathrm{C}$. On the basis of all these studies, a DES-based method $\mathbf{C}$ was established to implement the synthesis of $4 \mathbf{a}$ : $\mathrm{FeCl}_{3} \cdot 6 \mathrm{H}_{2} \mathrm{O} /$ meglumine (1:2)- $\mathrm{H}_{2} \mathrm{O}$ (50 wt\% with respect to the weight of DES) $(15 \mathrm{~mol} \%), 80{ }^{\circ} \mathrm{C}$, and $10 \mathrm{~h}$. It should be noted that, without adding water component, $\mathrm{FeCl}_{3} \cdot 6 \mathrm{H}_{2} \mathrm{O} /$ meglumine DES can also catalyze the reaction very well, and the yield of $\mathbf{4 a}$ reached $72 \%$ under the identical conditions (entry 10). In fact, even $300 \mathrm{wt} \%$ of water was added, the reaction still proceeded very well with the aid of $\mathrm{FeCl}_{3} \cdot 6 \mathrm{H}_{2} \mathrm{O} /$ meglumine DES, and the yield of $4 \mathbf{a}$ reached $67 \%$ (see SI, Figure S2). This result manefasted that $\mathrm{FeCl}_{3} \cdot 6 \mathrm{H}_{2} \mathrm{O} / \mathrm{meglumine}$ DES might be indeed a suitable catalytic system to update bio-based water-containing glycolaldehyde to value-added products.

Having three different methods in hand, we studied the scope of substrate, and the results are given in Scheme 1. A wide range of $\square$-ketoesters were used to assemble with 1a and indole 3a. Three methods are all effective to promote the reactions, and the corresponding dihydrofurans were obtained in generally good yields $(\mathbf{4 b}-\mathbf{d}, \mathbf{4 g}-\mathbf{m}$, and 4o- $\mathbf{q}$ ). When the reactions were performed in organic solvents, as evidenced by the results in Scheme 1, method A displayed superior catalytic ability than method $\mathbf{B}$. Double and triple bonds, ether and acrylate moiety can all be delivered uneventfully into the product molecules $(\mathbf{4 g - 4 i}, \mathbf{4 q})$. An acid-liable cyclopropyl-containing $\square$-ketoeaster is also amenable to this three-component reaction, affording the desired product $\mathbf{4} \mathbf{m}$ in $>53 \%$ yield. $\square$-Ketoesters with a heterocyclic group, such as furan-2-yl and thiophene2-yl, are also applicable in this reaction, and the desired dihydrofurans $4 \mathbf{o}$ and $\mathbf{4 p}$ were obtained in quite good yield. In all the reactions of $\square$-ketoesters, method $\mathbf{C}$ that involves the use of DES as dual solvent/catalyst seems slightly less effective compared with method $\mathbf{A}$ and $\mathbf{B}$. This can also be verified by the reactions of 1,3-diketones. While the expected products can be obtained in at maximum moderate yields with methods $\mathbf{A}$ and B, only by-product furans were isolated with method C. (4e-f, 4n). However, limitations of this three-component reaction were also observed. Attempts to use ethyl trifluoroacetoacetate and ethyl 4-chloroacetoacetate as substrate failed.

We also probe the scope of the reaction with respect to indole component. In most of the cases, three methods were used in order for us to find the best system for each individual reaction. As shown in Scheme 1, indoles with different substituents smoothly reacted with $\mathbf{1 a}$ and $\mathbf{2 a}$, producing dihydrofuran products in fairly good yields. Both 
electron-rich and moderately electron-poor indoles readily participated in the reaction. However, those containing strongly electron-withdrawing groups, such as 5-cyanoindole and 5-nitroindole, failed to participate in the reaction. Different from the results obtained in extending the scope of 1,3-dicarbonyl component, the performance of method $\mathbf{A}$ is not always superior to method $B$. In the synthesis reactions of $\mathbf{4 x}$ and $\mathbf{4 y}$, the yields obtained with method $\mathbf{B}$ are even twice higher than that of method $\mathbf{A}$. In many cases, the yields obtained with method $\mathbf{C}$ are comparable with that obtained with organic solvent systems. However, when 2-phenylindoles were used, method $\mathbf{C}$ was found to be invalid perhaps due to the strong hydrophobicity of the indole compounds. Then we continued to explore the reactivity of glycolaldehyde analogues on the model reaction. When (4R)2,2-dimethyl-1,3-dioxolane-4-carboxadehyde was used as substrate, the desired dihydrofurans $\mathbf{4 a d}$ were obtained with method $\mathbf{A}$ and method $\mathbf{C}$ in quite good yield. And 2,5-dihydroxy-1,4-dithiane was also applicable in this reaction to obtain 2,3dihydrothiophene derivative.

It should be noted that the dihydrofuran ring system is found prevalently at the central position of diverse classes of naturally occurring and biologically active heterocycles. ${ }^{28}$ A plenty of syntheses of dihydrofurans are available which offers a variety of intermediates and reaction conditions. ${ }^{29} \mathrm{~A}$ large majority of synthetic approaches have

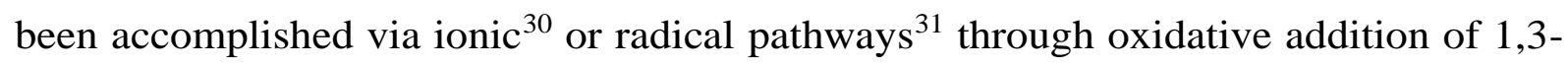
dicarbonyl compounds to appropriate olefins. Although all of these methodologies afford the dihydrofuran moiety in a reasonable yield, simple and efficient synthetic approaches still remain scarce. ${ }^{32}$ The present reaction offered thus an expedient method to synthesize dihydrofurans with an indo-3-yl substituent, which cannot be attained with the other methods.

A mechanism was also proposed as depicted in Scheme 2. Initial event of the reaction should be an acid-catalyzed deacetalization of 1a, leading to the formation of glycolaldehyde $\mathbf{1 b}$. This species can be trapped by 3a or $\mathbf{2 a}$. It can also be converted reversibly to its dimer 1c. Assembly of $\mathbf{1 b}$ with 2a through an aldol-type reaction occurred, and resulting in the generation of an intermediate I (the bottom pathway). An intramolecular hydrogen bond between the hydroxyl group and the ketone carbonyl may be formed in this intermediate. This increased the stability of $\mathbf{I}$, conferring thus $\mathbf{2 a}$ a priority to interact with $\mathbf{1 b}$ compared with 3a (the upper pathway). A Knoevenagel product II was then formed, which can be trapped by 3a through a Michael addition. The resulted intermediate III underwent an intramolecular dehydration, affording thus 
4a as the final product. The last step should be very fast, otherwise this three-component reaction wouldn't be successful. Michael addition of 3a to intermediate II may be crucial, and if it is insufficient, the equilibria of the reaction will channelize to the formation of 5a. Combined with the scope of substrate, we found that $\square$-ketoesters and indoles with moderate and strong electron-withdrawing including 5-cyanoindole and 5nitroindole, failed to participate in the reaction, because of their weakly nucleophilicity. In addition, we have explored the effect of the time course on the reaction. When the reaction could take place at room temperature, compared with method $\mathbf{B}$ and $\mathbf{C}$, method A exhibited fast reaction time, high yield of $\mathbf{4 a}$ and trace yield of by-product $\mathbf{5 a}$, had higher activation ability for indole. At $80{ }^{\circ} \mathrm{C}$, Method $\mathbf{B}$ had higher activation ability for indole.

From the perspective of green chemistry, DESs prepared by mechanical mixing method at moderate temperature have become promising alternative replacement to the hazardous organic solvents. Their preparation is simple and generally minimizes the volatilization of organic solvent. And they were recycled and easy to biodegradable to aviod the production of waste. In fact, the real advantages of using the DES as dual solvent/catalyst in the title reaction came from considering the following factors: (i) recyclability and (ii) feasibility of using an aqueous solution of glycolaldehdye. To investigate the recyclability, the progress of a three-component reaction driven by $\mathrm{FeCl}_{3} \cdot 6 \mathrm{H}_{2} \mathrm{O} /$ meglumine was recorded by a camara, and the pictures were collected in Figure 4. The DES is a dark brown fluid (Fig. 4a). After adding all of the starting materials, owing to the high viscosity of the DES at room temperature, a biphasic system could be visually observed (Fig. 4b). During the reaction, a homogeneous liquid was formed (Fig. 4c). At the end of the reaction, the formed products can be isolated through extraction with a mixture compose of heptane and ethyl acetate $\left(H / E_{v / v}=5: 1\right)($ Fig. $4 d)$. The DES can thus be recovered and reused. Then we investigated the recycling performance of DES in the model reaction. The results are shown in Table 3. After four consecutive runs, the $\mathrm{FeCl}_{3} \cdot 6 \mathrm{H}_{2} \mathrm{O} /$ meglumine is still capable of catalyzing the model reaction in $64 \%$ yield. TGA analysis revealed that the weight losses of fresh and recovered $\mathrm{FeCl}_{3} \cdot 6 \mathrm{H}_{2} \mathrm{O}$ /meglumine DES remained consistent (Figure 3B). By comparing FT-IR spectra of fresh and recovered $\mathrm{FeCl}_{3} \cdot 6 \mathrm{H}_{2} \mathrm{O} /$ meglumine DES (Figure 3D), it can be found that the absorption peaks almost had no change. The DSC curves of fresh and recovered $\mathrm{FeCl}_{3} \cdot 6 \mathrm{H}_{2} \mathrm{O}$ /meglumine DES exhibited the same glass transition temperature 
(see SI, Figure S3). The results indicate that $\mathrm{FeCl}_{3} \cdot 6 \mathrm{H}_{2} \mathrm{O} /$ meglumine DES is indeed stable and recyclable in the model synthesis reaction.

To investigate the feasibility of using bio-based glycolaldehyde, commercially available glycolaldehyde was dissolved in water to prepare two solutions with different concentrations (25 wt \% and $50 \mathrm{wt} \%$ ) and then utilized in the three-component reaction. As shown in Scheme 3, the reaction with an aqueous solution of glycolaldehyde (25 wt $\%$ ) proceeded very well with the aid of $\mathrm{FeCl}_{3} \cdot 6 \mathrm{H}_{2} \mathrm{O} /$ meglumine DES, producing $4 \mathbf{a}$ in $51 \%$ yield after $10 \mathrm{~h}$ of reaction at $80{ }^{\circ} \mathrm{C}$. When a concentrated solution of glycolaldehyde (50 wt\%) was used, the yield keeps almost constant. However, in an organic system, $\mathrm{Sc}(\mathrm{OTf})_{3} /$ nitromethane, the aqueous solution of glycolaldehyde can be hardly used, and the yield of $4 \mathbf{a}$ reached only $8 \%$. And $\mathrm{Ni}\left(\mathrm{ClO}_{4}\right)_{2} \cdot 6 \mathrm{H}_{2} \mathrm{O}$ /acetonitrile worked slightly, and the yield of $\mathbf{4 a}$ can be improved to $26 \%$. These results demonstrated that using $\mathrm{FeCl}_{3} \cdot 6 \mathrm{H}_{2} \mathrm{O} /$ meglumine as dual solvent/catalyst indeed enabled the utilization of bio-based glycolaldehyde in the model three-component assembly reactions. We found also that the DES can be recycled and reused in this reaction, and the catalytic activity remained perfect in the second run.

\section{Conclusions}

To update the use of bio-based glycolaldehyde, a hydrolysis product of cellulose or glucose, as a platform molecule towards value-added products, we first developed an expedient three-component reaction of indole, glycolaldehyde acetal and 1,3-dicarbonyl compound in organic solvent systems. Both $\mathrm{Sc}(\mathrm{OTf})_{3}$ and $\mathrm{Ni}\left(\mathrm{ClO}_{4}\right)_{2} \cdot 6 \mathrm{H}_{2} \mathrm{O}$ are able to catalyze the reaction efficiently, providing a hitherto unreported class of 3-(indol-3-yl)2,3-dihydrofurans in good to excellent yields. We then turned to aqueous systems for which the previous conditions were not giving satisfactory results. To enable the use of aqueous solution of glycolaldehyde, we developed a novel DES, $\mathrm{FeCl}_{3} \cdot 6 \mathrm{H}_{2} \mathrm{O} /$ meglumine. This system was proved to be an efficient and a watercompatible promoting medium for the synthesis of dihydrofuran derivatives via the three-component reaction. The use of bio-based glycolaldehyde as starting material is also very successful. The system can also be recycled without significant loss of its activity. This work may give an inspiration to organic chemists that bio-based glycolaldehyde should be a useful C2 building block, which has unique reactivities and can be hopefully applied in many organic transformations. In the future, much effort should be paid to (i) explore suitable methods for large scale synthesis of bio-based 
glycolaldehyde, and (ii) develop appropriate catalytic systems for enabling the use of water-containing bio-based glycolaldehyde.

\section{Experimental}

Unless otherwise noted, all reagents were purchased from commercial suppliers and used without purification. ${ }^{1} \mathrm{H}$ and ${ }^{13} \mathrm{C}$ NMR spectra were recorded on a Bruker AV-400. Chemical shifts are expressed in parts per million relative to $\mathrm{Me}_{4} \mathrm{Si}$ in $\mathrm{CDCl}_{3}$ or DMSO$d_{6}$. IR spectra were recorded with a FT-IR Bruker (EQUINOX 55) spectrometer using $\mathrm{KBr}$ pellets or neat liquid. The thermal stability of the samples was characterized by thermogravimetric analysis (TGA, TGA-7, Perkin-Elmer, USA) at a heating rate of $10{ }^{\circ} \mathrm{C} \mathrm{min}-1$ in an argon flow $\left(20 \mathrm{~mL} \mathrm{~min}^{-1}\right)$. Differential scanning calorimetry (DSC) measurements were conducted in a DSC Q2000 (Thermal Analyst Co., TA Instruments, USA) to determine the glass transition temperature $\left(T_{g}\right)$ of DESs. All experiments were performed from $30{ }^{\circ} \mathrm{C}$ to $-60{ }^{\circ} \mathrm{C}$ at a heating rate $10{ }^{\circ} \mathrm{C} \mathrm{min}{ }^{-1}$ in an argon atmosphere at $50 \mathrm{~mL} \mathrm{~min}^{-1}$.

Synthesis of 3i, 30 and 3p: a solution of methyl acetoacetate $(2 \mathrm{mmol})$ in toluene was mixed with propargyl alcohol $(2 \mathrm{mmol})$ and triphenylphosphine $(0.2 \mathrm{mmol})$ to obtain (2propynyl) 3-oxobutanoate (3i). ${ }^{34}$ The mixture was then refluxed for $6 \mathrm{~h}$. The progress of the reactions was monitored by TLC. After the reaction, the reaction mixture was cooled to room temperature, and the product was obtained in $83 \%$ yield by isolation with preparative TLC (eluting solution: petroleum ether/ethyl acetate $=5 / 1(\mathrm{v} / \mathrm{v})$ ). Synthesis of the other compounds was performed by an analogous procedure.

Synthesis of $\mathbf{4 a}$ and $\mathbf{5 a}$ : the reaction was conducted in a $10 \mathrm{~mL} \mathrm{~V}$-type flask equipped with a triangular magnetic stirring bar. A solution of ethyl acetoacetate $(0.4 \mathrm{mmol})$ in $\mathrm{CH}_{3} \mathrm{NO}_{2}(1.0 \mathrm{~mL})$ was mixed with glycolaldehyde diethyl acetal $(0.4 \mathrm{mmol})$, indole $(0.2$ mmol) and $\mathrm{Sc}(\mathrm{OTf})_{3}(0.01 \mathrm{mmol})$ to obtain target product (4a). The mixture was then stirred at room temperature for $1 \mathrm{~h}$. After the reaction, the product was obtained in $81 \%$ by isolation with preparative TLC (eluting solution: petroleum ether/ethyl acetate $=5 / 1$ $(\mathrm{v} / \mathrm{v}))$. All tests for substrate scope were performed with an analogous procedure (method A). And a solution of ethyl acetoacetate $(0.4 \mathrm{mmol})$ in $\mathrm{CH}_{3} \mathrm{CN}(1.0 \mathrm{~mL})$ was mixed with glycolaldehyde diethyl acetal $(0.4 \mathrm{mmol})$, indole $(0.2 \mathrm{mmol})$ and $\mathrm{Ni}\left(\mathrm{ClO}_{4}\right)_{2} \cdot 6 \mathrm{H}_{2} \mathrm{O}(0.08 \mathrm{mmol})$ to obtain target product $(\mathbf{4 a})$. The mixture was then stirred at $80^{\circ} \mathrm{C}$ for $6 \mathrm{~h}$. After the reaction, the mixture was cooled to room temperature, and the 
product was obtained in $79 \%$ by isolation with preparative TLC (eluting solution: petroleum ether/ethyl acetate $=5 / 1(\mathrm{v} / \mathrm{v}))$. All tests for substrate scope were performed with an analogous procedure $(\operatorname{method} \mathbf{B})$. And a solution of ethyl acetoacetate $(0.4 \mathrm{mmol})$ was mixed with glycolaldehyde diethyl acetal $(0.4 \mathrm{mmol})$, indole $(0.2 \mathrm{mmol})$ and $\mathrm{FeCl}_{3} \cdot 6 \mathrm{H}_{2} \mathrm{O} /$ meglumine- $\mathrm{H}_{2} \mathrm{O}(0.03 \mathrm{mmol})$ to obtain target product $(\mathbf{4 a})$. The mixture was then stirred at $80{ }^{\circ} \mathrm{C}$ for $10 \mathrm{~h}$. After the reaction, the mixture was cooled to room temperature, and the product was obtained through extraction with a mixture compose of heptane and ethyl acetate $(\mathrm{H} / \mathrm{Ev} / \mathrm{v}=5: 1)$. And then the formed products can be isolated with preparative TLC (eluting solution: petroleum ether/ethyl acetate $=5 / 1(\mathrm{v} / \mathrm{v})$ ) (method C).

\section{Conflicts of interest}

The authors declare no competing financial interest.

\section{Acknowledgements}

The authors thank the National Natural Science Foundation of China (2171101076 and 21872060) and the Fundamental Research Funds for the Central Universities of China (2016YXZD033) for the financial support. The Cooperative Innovation Center of Hubei Provinceand is also acknowledgeds.

\section{References}

1 (a) S. Wang, G. Dai, H. Yang, Z. Luo, Prog. Energy Combust. Sci., 2017, 62, 33-86; (b) J. F. Jenck, F. Agterberg, M. J. Droescher, Green Chem., 2004, 6, 544-556. (c) Y. Zhang, Z. G. Yuan, B. Hu, J. Deng, Y. Fu, Q. Lu, Green Chem., 2019, 21, 812-820.

2 (a) A. Demirbas, Energy Convers. Manage., 2009, 50, 2782-2801; (b) C. R. Vitasari, G. W. Meindersma, A. B. De Haan, Bioresour. Technol., 2011, 102, 7204-7210; (c) C. R. Vitasari, G. W. Meindersma, A. B. De Haan, Green Chem., 2012, 14, 321-325; (d) D. Mohan, C. U. Pittman, P. H. Steele, Energy Fuels, 2006, 20, 848-889.

3 G. Xu, A. Q. Wang, J. F. Pang, T. Zhang, Appl. Catal. A-Gen, 2015, 502, 65-70.

4 R. Flamini, A. D. Vedova, J. Agric. Food Chem., 2003, 51, 2300-2303.

5 (a) G. F. Liang, A. Q. Wang, L. Li, T. Zhang, Angew. Chem. Int. Ed., 2017, 56, 30503054; (b) N. Ji, T. Zhang, A. Q. Wang, X. D. Wang, Angew. Chem. Int. Ed., 2008, 47, 8510-8513; (c) K. Usami, A. Okamoto, Org. Biomol. Chem., 2017, 15, 8888-8893. 
6 G. Cassone, J. Sponer, J. E. Sponer, F. Saijia, Chem. Commun., 2018, 54, 3211-3214.

7 (a) W. F. Zhao, X. P. Chi, H. Li, J. He, S. Yang, Green Chem., 2019, 21, 567-577. (b) S. Ranganathan, S. Zeitlhofer, V. Sieber, Green Chem., 2017, 19, 2576-2586. (c) A. P. Abbott, A. Z. M. Al-Bassam, A. Goddard, R. C. Harris, M. Wieland, Green Chem., 2017, 19, 2225-2233. (d) F. Sebest, L. Casarrubios, H. S. Rzepa, A. J. P. White, S. DíezGonzález, Green Chem., 2018, 20, 4023-4035.

8 (a) D. Carriazo, M. C. Serrano, M. C. Gutierrez, M. L. Ferrer, Chem. Soc. Rev., 2012, 41, 4996-5014; (b) E. J. Smith, A. P. Abbott, K. S. Ryeder, Chem. Rev., 2014, 114, 11060-11082. (c) H. G. Cruz, N. Jordăo, L. C. Branco, Green Chem., 2017, 19, 1653 1658. (d) J. Y. Jiang, C. Y. Yan, X. H. Zhao, Z. M. Xue, T. C. Mu, Green Chem., 2017, 19, 3023-3031.

9 (a) A. Wang, P. Xing, X. Zhang, H. Cao, G. Yang, RSC. Adv., 2015, 5, 59022-59026;

(b) P. H. Tran, H. T. Nguyen, P. E. Hansen, RSC. Adv., 2016, 6, 37031-37038.

10 (a) M. Obst, B. Koenig, Eur. J. Org. Chem., 2018, 201, 4213-4232; (b) M. Jablonsky, A. Skulcova, A. Malvis, J. J. Sima, Biotechnol., 2018, 282, 46-66; (c) Y. Liu, J. B. Friesen, J. B. McAlpine, D. C. Lankin, S. N. Chen, G. F. Pauli, J. Nat. Prod., 2018, 81, 679-690; (d) C. J. Clarke, W. C. Tu, O. Levers, A. Brohl, J. P. Hallett, Chem. Rev., 2018, 118, 747-800.

11 For selected examples, see: (a) A. T. Merrit, S. V. Ley, Nat. Prod. Rep., 1992, 9, $243-$ 287; (b) J. P. Michael, Nat. Prod. Rep., 2000, 17, 603-620; (c) T. Koike, T. Takai, Y. Hoashi, K. Hirai, O. Uchikawa, J. Med. Chem., 2011, 54, 4207-4218. (d) M. J. Somerville, P. L. Katavic, L. K. Lambert, M. Gavagnin, M. G. Banwell, M. J. Garson, J. Nat. Prod., 2012, 75, 1618-1624. (e) K. Sugimoto, K. Tamura, N. Ohta, C. Tohda, N. Toyooka, H. Nemoto, Y. Matsuya, Bioorg. Med. Chem. Lett., 2012, 22, 449-452. (f) Y. Zhang, H. Zhong, T. Wang, D. Geng, M. Zhang, K. Li, Eur. J. Med. Chem., 2012, 48, 69-80. (g) M. R. Lambu, Z. M. A. Judeh, Green Chem., 2019, 21, 821-829.

12 For reviews, see: (a) J. Iqbal, B. Bhatia, N. K. Nayyar, Chem. Rev., 1994, 94, 519-584. (b) B. B. Snider, Chem. Rev., 1996, 96, 339-364. (c) B. Godoi, R. F. Schumacher, G. Zeni, Chem. Rev., 2011, 111, 2937-2980. (d) J. Le Bras, J. Muzart, Chem. Soc. Rev., 2014, 43, 3003-3040. (e) R. Zimmer, H. U. Reissig, Chem. Soc. Rev., 2014, 43, 2888 2903.

13 (a) W. Huang, C. H. Liu, Y. L. Gu, Adv. Synth. Catal., 2017, 359, 1811-1818; (b) Z. F. Jia, K. W. Wang, B. E. Tan, Y. L. Gu, Adv. Synth. Catal., 2017, 359, 78-88; (c) C. H. Liu, L. Zhou, D. Jiang, Y. L. Gu, Asian J. Org. Chem., 2016, 5, 367-372; (d) C. H. Liu, 
L. Zhou, W. B. Huang, M. Wang, Y. L. Gu, Adv. Synth. Catal., 2016, 358, 900-918; (e)

C. Cheng, C. H. Liu, Y. L. Gu, Tetrahedron, 2015, 71, 8009-8017; (f) A. Taheri, B. Lai,

C. Cheng, Y. L. Gu, Green Chem., 2015, 17, 812-816.

14 See a review: (a) P. Ravichandiran, B. Lai, Y. L. Gu, Chem. Rec., 2017, 17, 142-183.

See some examples: (b) Y. L. Gu, F. Wu, J. Yang, Adv. Synth. Catal., 2018, 360, 27272741; (c) J. Yang, F. Mei, S. Fu, Y. L. Gu, Green Chem., 2018, 20, 1367-1374; (d) C. H. Liu, W. B. Huang, M. Wang, B. Pan, Y. L. Gu, Adv. Synth. Catal., 2016, 358, 22602266; (e) S. Sun, C. Cheng, J. Yang, A. Taheri, D. Jiang, B. Zhang, Y. L. Gu, Org. Lett., 2014, 16, 4520-4523.

15 (a) A. T. Nielsen, G. W. Lawrence, J. Org. Chem., 1977, 42, 2900-2902; (b) W. M.

Koppes, M. E. Sitzmann, H. G. Adolph, J. Chem. Eng. Data, 1986, 31, 119-123.

16 Hydroxycarbonyl compounds can react with $\mathrm{C}-\mathrm{H}$ acids, such as malononitrile and 1,3dicarbonyl compounds, to form furans: (a) L. Tan, Z. Zhang, D. Gao, J. Luo, X. Ren, K. Ding, J. Med. Chem., 2016, 59, 6807-6825; (b) Z. J. Ding, F. Zhang, T. X. Xu, W. B. Wang, L. Jin, N. Y. Huang, Chin. J. Struct. Chem., 2017, 36, 1124-1129; (c) E. Nagy, Y. Liu, K. J. Prentice, K. W. Sloop, P. E. Sanders, B. Batchuluun, C. D. Hammond, M. B. Wheeler, T. B. Durham, J. Med. Chem., 2017, 60, 1860-1875.

17 Y. Ren, M. Li, J. Yang, J. Peng, Y. Gu, Adv. Synth. Catal., 2011, 353, 3473-3484.

18 (a) R. Gani, P. A. Crafts, M. J. Powell, L. Powell, J. H. Atherton, J. L. Cordiner, Chem.

Eng., 2006, 113, 30-43; (b) D. J. C. Constable, R. K. Henderson, Org. Proc. Res. Develop., 2007, 11, 133-137.

19 (a) C. J. Li, Acc. Chem. Res., 2002, 35, 533-538; (b) M. J. Earle, S. P. Katdare, K. R. Seddon, Org. Lett., 2004, 6, 707-710; (c) Q. H. Zhang, S. G. Zhang, Y. Q. Deng, Green Chem., 2011, 13, 2619-2637; (d) J. R. Hyde, P. Licence, M. Poliakoff, Appl. Catal. AGen, 2001, 222, 119-131; (e) N. Azizi, M. Khajeh, M. Alipour, Ind. Eng. Chem. Res., 2014, 53, 15561-15565. (f) J. Cao, L. Y. Chen, M. H. Li, F. L. Cao, E. Su, Green Chem., 2018, 20, 1879-1886.

20 (a) F. J. Liu, Z. M. Xue, X. H. Zhao, H. Y. Mou, J. He, T. C. Mu, Chem. Commun., 2018, 54, 6140-6143. (b) T. J. Park, S. H. Lee, Green Chem., 2017, 19, 910-913.

21 (a) A. P. Abbott, G. Capper, D. L. Davies, R. Rasheed, Inorg. Chem., 2004, 43, 34473452; (b) A. P. Abbott, G. Capper, D. L. Davies, R. Rasheed, Chem-Eur. J., 2004, 10, 3769-3774. 
22 (a) M. Hayyan, A. Abo-Hamad, M. A. AlSaadi, M. A. Hashim, Nanoscale Res. Lett., 2015, 10, 324-350; (b) H. M. Badawi, W. Förner, Spectrochim. Acta A, 2011, 78, 1162 1167.

23 (a) R. Ullah, M. Atilhan, B. Anaya, S. Aparicio, Phys. Chem. Chem. Phys., 2015, 17, 20941-20960; (b) S. L. Perkins, P. Painter, C. M. Colina, J. Chem. Eng. Data, 2014, 59, 3652-3662.

24 M. Agrawal, S. Gupta, A. Pich, N. E. Zafeiropoulos, M. Stamm, Chem. Mater., 2009, 21, 5343-5356.

25 L. Moradi, M. J. Tadayon, Saudi Chem. Soc., 2018, 22, 66-75.

26 A. A. Samarov, M. A. Smirnov, M. P. Sokolova, E. N. Popova, A. M. Toikka, Fluid Phase Equilibria, 2017, 448, 123-127.

27 Q. H. Zhang, S. Royer, F. Jérôme, Chem. Soc. Rev., 2012, 41, 7108-7146.

28 (a) J. Lee, J. H. Li, S. Oya, J. K. Snyder, J. Org. Chem., 1992, 57, 5301-5312; (b) P. A. Jacobi, H. G. Selnick, J. Org. Chem., 1990, 55, 202-209; (c) B. H. Lipshutz, Chem. Rev., 1986, 86, 795-819.

29 (a) Y. Fukude, H. Shiragami, K. Utimoto, H. Nozaki, J. Org. Chem., 1991, 56, 58165819; (b) K. Shishido, K. Umimoto, M. Shibuya, Heterocycles, 1990, 31, 597-598; (c) S. P. Tanis, M. C. McMills, T. A. Scahill, D. A. Kloosterman, Tetrahedron Lett., 1990, 31, 1977-1980; (d) R. L. Danheiser, E. J. Stormer, H. Koyama, D. S. Yamashita, C. A. Klade, J. Am. Chem. Soc., 1989, 111, 4407-4413;

30 (a) Y. R. Lee, J. K. Suk, Tetrahedron, 2002, 58, 2359-2367; (b) N. Aso, A. Ojida, G. Yang, O. J. Cha, E. Osawa, K. Kamematsu, J. Org. Chem., 1993, 58, 3960-3968.

31 J. Iqbal, B. Bhatia, N. K. Nayyar, Tetrahedron, 1991, 47, 6457-6468.

32 (a) M. E. Jung, L. J. Street, J. Am. Chem. Soc., 1994, 106, 8327-8329; (b) D. D. Sternbach, D. M. Rossana, Tetrahedron Lett., 1982, 23, 303-306.

33 (a) K. H. Kim, T. Dutta, J. Sun, B. Simmons, S. Singh, Green Chem., 2018, 20, 809815. (b) L. Cicco, N. R. Lombardía, M. J. R. Álvarez, J. G. Sabín, Green Chem., 2018, 20, 3468-3475.

34 J. S. Yadav, B. V. S. Reddy, A. D. Krishna, A. V. Narsaish, J. Mol. Catal. A-Chem., 2007, 261, 93-97. 
Table 1. Three-component reaction of $\mathbf{1 a}, \mathbf{2 a}$ and $\mathbf{3 a}{ }^{\mathrm{a}}$

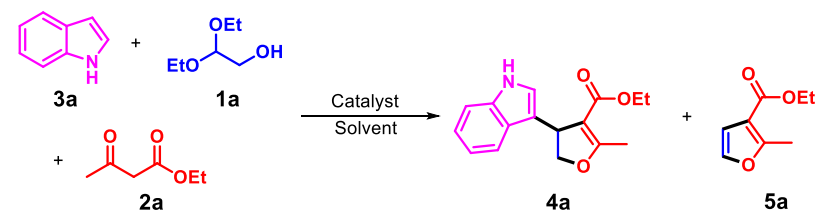

\begin{tabular}{|c|c|c|c|}
\hline \multirow{2}{*}{ entry } & \multirow{2}{*}{ catalyst and specified conditions } & \multicolumn{2}{|c|}{ yield $(\%)^{b}$} \\
\hline & & $4 \mathbf{a}$ & $5 \mathbf{a}^{\mathrm{c}}$ \\
\hline 1 & catalyst-free, in $\mathrm{CH}_{3} \mathrm{CN}$ or $\mathrm{CH}_{3} \mathrm{NO}_{2}, 80{ }^{\circ} \mathrm{C}, 1 \mathrm{~h}$ & 0 & 0 \\
\hline 2 & $\mathrm{Sc}(\mathrm{OTf})_{3}(5 \mathrm{~mol} \%), \mathrm{CH}_{3} \mathrm{NO}_{2}$, r.t., 1 h $(\operatorname{method} \mathbf{A})$ & 81 & 0 \\
\hline 3 & $\mathrm{Al}(\mathrm{OTf})_{3}(5 \mathrm{~mol} \%), \mathrm{CH}_{3} \mathrm{NO}_{2}$, r.t., $1 \mathrm{~h}$ & 50 & 16 \\
\hline 4 & $\mathrm{Fe}(\mathrm{OTf})_{3}(5 \mathrm{~mol} \%), \mathrm{CH}_{3} \mathrm{NO}_{2}$, r.t., $1 \mathrm{~h}$ & 63 & 14 \\
\hline 5 & $\mathrm{Ni}(\mathrm{OTf})_{2}$ or $\mathrm{Ni}\left(\mathrm{ClO}_{4}\right)_{2} \cdot 6 \mathrm{H}_{2} \mathrm{O}(5 \mathrm{~mol} \%), \mathrm{CH}_{3} \mathrm{NO}_{2}$, r.t., $1 \mathrm{~h}$ & 0 & 0 \\
\hline 6 & PTSA ( 5 mol\%), $\mathrm{CH}_{3} \mathrm{NO}_{2}$, r.t., $1 \mathrm{~h}$ & 0 & 0 \\
\hline 7 & $\mathrm{Sc}(\mathrm{OTf})_{3}(5 \mathrm{~mol} \%), \mathrm{CH}_{3} \mathrm{CN}$, r.t., $1 \mathrm{~h}$ & 73 & 8 \\
\hline 8 & $\operatorname{Sc}(\mathrm{OTf})_{3}(5 \mathrm{~mol} \%)$, DCE, r.t., $1 \mathrm{~h}$ & 47 & 14 \\
\hline 9 & $\mathrm{Sc}(\mathrm{OTf})_{3}(5 \mathrm{~mol} \%)$, Toluene, r.t., $1 \mathrm{~h}$ & 39 & 17 \\
\hline 10 & $\mathrm{Sc}(\mathrm{OTf})_{3}(5 \mathrm{~mol} \%), \mathrm{EtOH}$, r.t., $1 \mathrm{~h}$ & 0 & 0 \\
\hline 11 & $\mathrm{Ni}\left(\mathrm{ClO}_{4}\right)_{2} \cdot 6 \mathrm{H}_{2} \mathrm{O}(20 \mathrm{~mol} \%), \mathrm{CH}_{3} \mathrm{CN}, 80^{\circ} \mathrm{C}, 6 \mathrm{~h}(\operatorname{method} \mathbf{B})$ & 79 & 12 \\
\hline 12 & $\mathrm{Ni}(\mathrm{OTf})_{2}(20 \mathrm{~mol} \%), \mathrm{CH}_{3} \mathrm{CN}, 80^{\circ} \mathrm{C}, 6 \mathrm{~h}$ & 61 & 15 \\
\hline 13 & $\mathrm{Ni}\left(\mathrm{ClO}_{4}\right)_{2} \cdot 6 \mathrm{H}_{2} \mathrm{O}(20 \mathrm{~mol} \%), \mathrm{DCE}, 80^{\circ} \mathrm{C}, 6 \mathrm{~h}$ & 57 & 16 \\
\hline 14 & $\mathrm{Ni}\left(\mathrm{ClO}_{4}\right)_{2} \cdot 6 \mathrm{H}_{2} \mathrm{O}(20 \mathrm{~mol} \%)$, Toluene, $80^{\circ} \mathrm{C}, 6 \mathrm{~h}$ & 13 & 0 \\
\hline 15 & $\mathrm{Ni}\left(\mathrm{ClO}_{4}\right)_{2} \cdot 6 \mathrm{H}_{2} \mathrm{O}(20 \mathrm{~mol} \%), \mathrm{EtOH}, 80^{\circ} \mathrm{C}, 6 \mathrm{~h}$ & 11 & 0 \\
\hline
\end{tabular}

a: 1a $(0.4 \mathrm{mmol}), 2 \mathbf{a}(0.4 \mathrm{mmol}), 3 \mathbf{a}(0.2 \mathrm{mmol})$, solvent $(1.0 \mathrm{~mL}){ }^{\text {b: }}$ : Isolated yield, and calculated with respect to $\mathbf{3 a}{ }^{\text {c: }}$ : Isolated yield, and calculated with respect to $\mathbf{1 a}$. 
Table 2. Three-component reaction of 1a, 2a and 3a in DES-water mixtures. ${ }^{\text {a }}$

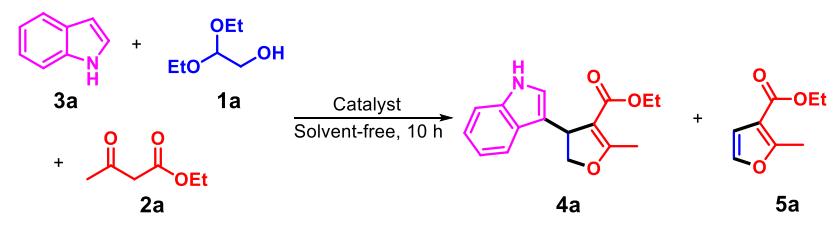

\begin{tabular}{llll}
\hline \multirow{2}{*}{ entry } & catalyst and specified conditions & \multicolumn{2}{c}{ yield $(\%)^{\mathrm{b}}$} \\
\cline { 3 - 5 } & & $\mathbf{4 a}$ & $\mathbf{5 a}^{\mathrm{c}}$ \\
\hline 1 & $\mathrm{ChCl} /$ ethylene glycol $(1: 2)-\mathrm{H}_{2} \mathrm{O}(5 \mathrm{~mol} \%), 60{ }^{\circ} \mathrm{C}$ & 0 \\
2 & $\mathrm{ZnCl}_{2} /$ ethylene glycol $(1: 2)-\mathrm{H}_{2} \mathrm{O}(5 \mathrm{~mol} \%), 60{ }^{\circ} \mathrm{C}$ & 14 & 17 \\
3 & $\mathrm{FeCl}_{3} \cdot 6 \mathrm{H}_{2} \mathrm{O} /$ ethylene glycol $(1: 2)-\mathrm{H}_{2} \mathrm{O}(5 \mathrm{~mol} \%), 60{ }^{\circ} \mathrm{C}$ & 16 & 21 \\
4 & $\mathrm{FeCl}_{3} \cdot 6 \mathrm{H}_{2} \mathrm{O} /$ glycerol $(1: 2)-\mathrm{H}_{2} \mathrm{O}(5 \mathrm{~mol} \%), 60{ }^{\circ} \mathrm{C}$ & 43 & 24 \\
5 & $\mathrm{FeCl}_{3} \cdot 6 \mathrm{H}_{2} \mathrm{O} /$ meglumine $(1: 2)-\mathrm{H}_{2} \mathrm{O}(5 \mathrm{~mol} \%), 60{ }^{\circ} \mathrm{C}$ & 46 & 22 \\
6 & $\mathrm{FeCl}_{3} \cdot 6 \mathrm{H}_{2} \mathrm{O} /$ meglumine $(1: 2)-\mathrm{H}_{2} \mathrm{O}(15 \mathrm{~mol} \%), 60{ }^{\circ} \mathrm{C}$ & 63 & 26 \\
7 & $\mathrm{FeCl}_{3} \cdot 6 \mathrm{H}_{2} \mathrm{O} /$ meglumine $(1: 2)-\mathrm{H}_{2} \mathrm{O}(15 \mathrm{~mol} \%), 80{ }^{\circ} \mathrm{C}(\operatorname{method}$ & 73 & 25 \\
& $\mathrm{C}^{2}$ & & \\
9 & $\mathrm{FeCl}_{3} \cdot 6 \mathrm{H}_{2} \mathrm{O} /$ meglumine $(1: 1)-\mathrm{H}_{2} \mathrm{O}(15 \mathrm{~mol} \%), 80{ }^{\circ} \mathrm{C}$ & 0 & 0 \\
10 & $\mathrm{FeCl}_{3} \cdot 6 \mathrm{H}_{2} \mathrm{O} /$ meglumine $(1: 3)-\mathrm{H}_{2} \mathrm{O}(15 \mathrm{~mol} \%), 80{ }^{\circ} \mathrm{C}$ & 12 & 15 \\
11 & $\mathrm{FeCl}_{3} \cdot 6 \mathrm{H}_{2} \mathrm{O} /$ meglumine $(1: 2)(15 \mathrm{~mol} \%), 80{ }^{\circ} \mathrm{C}$ & 72 & 23 \\
\hline
\end{tabular}

a: 1a $(0.4 \mathrm{mmol}), \mathbf{2 a}(0.4 \mathrm{mmol}), 3 \mathbf{a}(0.2 \mathrm{mmol})$, water $(50 \mathrm{wt} \%)$ was added in DESs. ${ }^{\text {b: }}$ Isolated yield, and calculated with respect to 3a. ${ }^{\text {c: }}$ Isolated yield, and calculated with respect to $\mathbf{1 a}$.

Table 3. Reusability of $\mathrm{FeCl}_{3} \cdot 6 \mathrm{H}_{2} \mathrm{O} /$ meglumine DES. ${ }^{\text {a }}$

\begin{tabular}{lllll}
\hline Run & 1 & 2 & 3 & 4 \\
Yield (\%) 4a & 73 & 67 & 65 & 64 \\
\hline${ }^{\mathrm{a}}$ : Method C: $\mathbf{1 a}(0.4 \mathrm{mmol}), \mathbf{2 a}(0.4 \mathrm{mmol}), \mathbf{3 a}(0.2 \mathrm{mmol}), \mathrm{FeCl}_{3} \cdot 6 \mathrm{H}_{2} \mathrm{O} /$ meglumine DES (15 \\
mol\%), $80{ }^{\circ} \mathrm{C}, 10 \mathrm{~h}$.
\end{tabular}



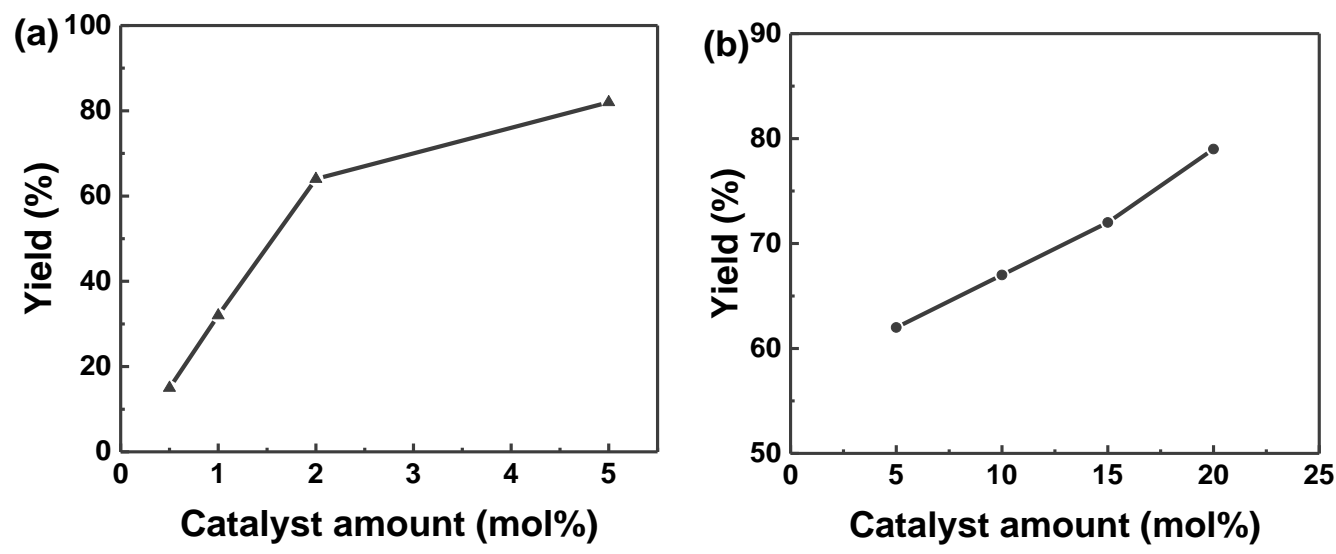

Figure 1. Effect of the catalyst amount on the model reaction. (a) $\mathrm{Sc}(\mathrm{OTf})_{3} /$ nitromethane, r.t., $1 \mathrm{~h}(\operatorname{method} \mathrm{A})$. (b) $\mathrm{Ni}\left(\mathrm{ClO}_{4}\right)_{2} \cdot 6 \mathrm{H}_{2} \mathrm{O} /$ acetonitrile, $80{ }^{\circ} \mathrm{C}, 6 \mathrm{~h}$ (method B).
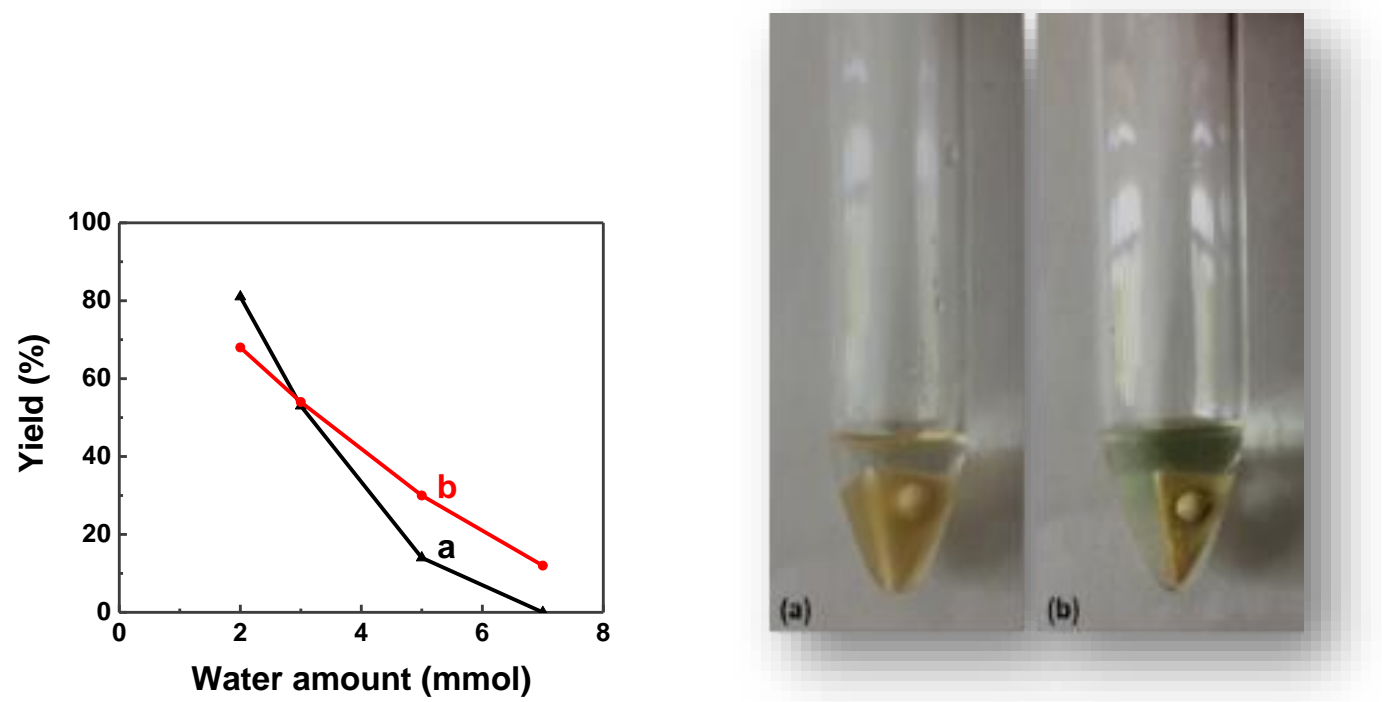

Figure 2. Effect of the water amount on the model reaction. (a) $\operatorname{Sc}(\mathrm{OTf})_{3} /$ nitromethane, r.t., 1 h (method A). (b) $\mathrm{Ni}\left(\mathrm{ClO}_{4}\right)_{2} \cdot 6 \mathrm{H}_{2} \mathrm{O} /$ acetonitrile, $80{ }^{\circ} \mathrm{C}, 6 \mathrm{~h}$ (method $\mathbf{B}$ ). 

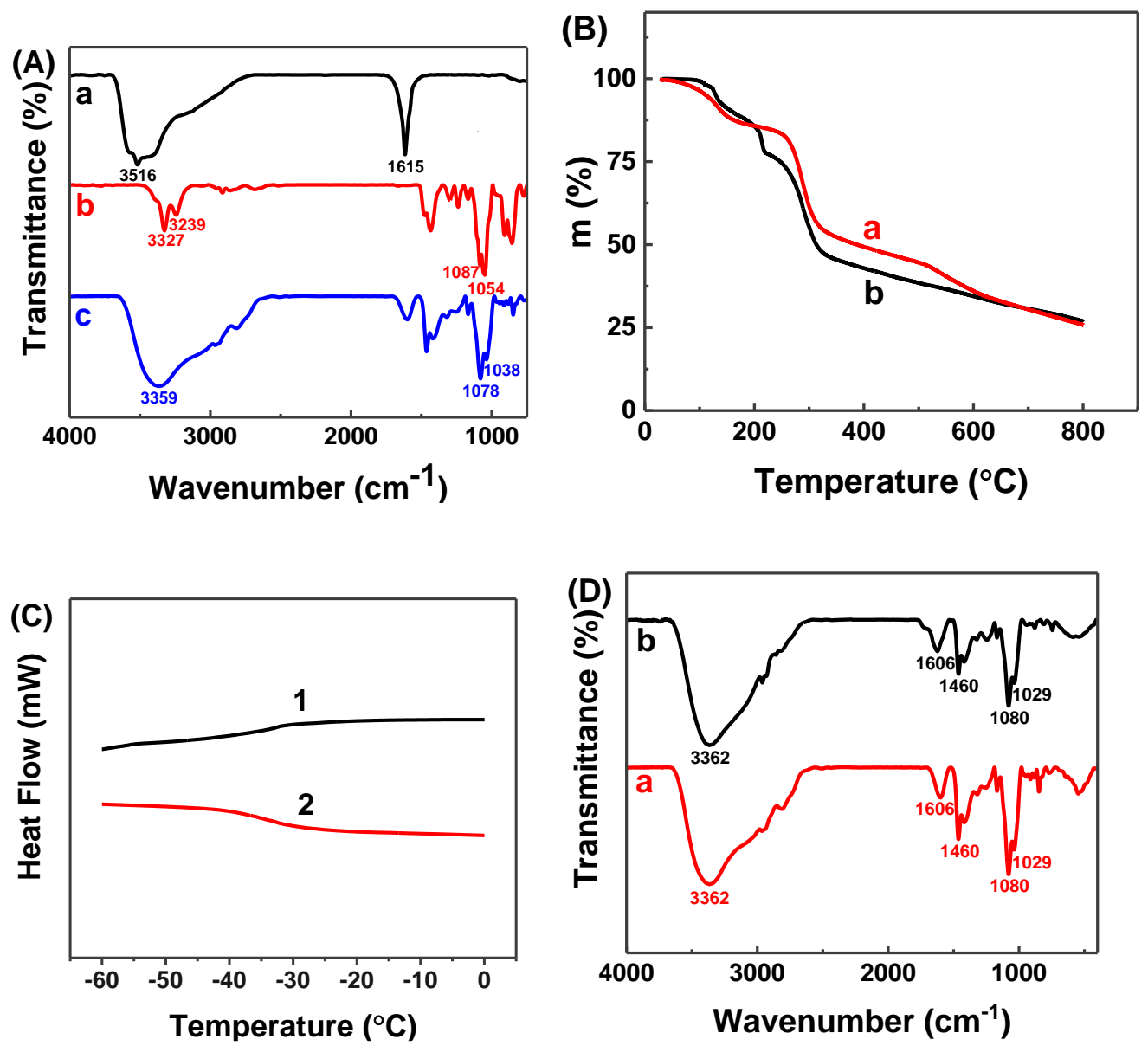

Figure 3. FTIR spectroscopy of (a) $\mathrm{FeCl}_{3} \cdot 6 \mathrm{H}_{2} \mathrm{O}$ by liquid film; (b) meglumine by $\mathrm{KBr}$; (c) $\mathrm{FeCl}_{3} \cdot 6 \mathrm{H}_{2} \mathrm{O} /$ meglumine DES by liquid film (A); TGA analysis of (a) fresh $\mathrm{FeCl}_{3} \cdot 6 \mathrm{H}_{2} \mathrm{O} /$ meglumine DES; (b) recovered $\mathrm{FeCl}_{3} \cdot 6 \mathrm{H}_{2} \mathrm{O} /$ meglumine DES under Argon atmosphere (B); DSC of $\mathrm{FeCl}_{3} \cdot 6 \mathrm{H}_{2} \mathrm{O} /$ meglumine DES (line 1: the first scan, line 2: the second scan) (C); FTIR spectroscopy of (a) fresh $\mathrm{FeCl}_{3} \cdot 6 \mathrm{H}_{2} \mathrm{O} /$ meglumine DES by liquid film; (b) recovered $\mathrm{FeCl}_{3} \cdot 6 \mathrm{H}_{2} \mathrm{O} /$ meglumine DES by liquid film (D). 

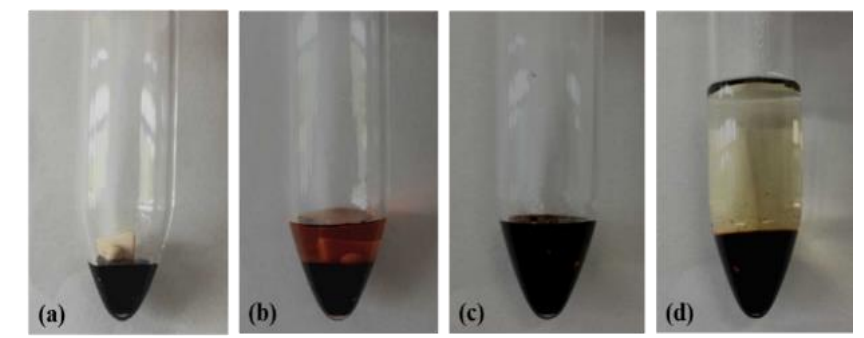

Figure 4. Progress of the model reaction in the DES. (a) $\mathrm{FeCl}_{3} \cdot 6 \mathrm{H}_{2} \mathrm{O} /$ meglumine DES; (b) after adding all of the starting materials; (c) at the end of the reaction; (d) product extraction with organic solvent. 


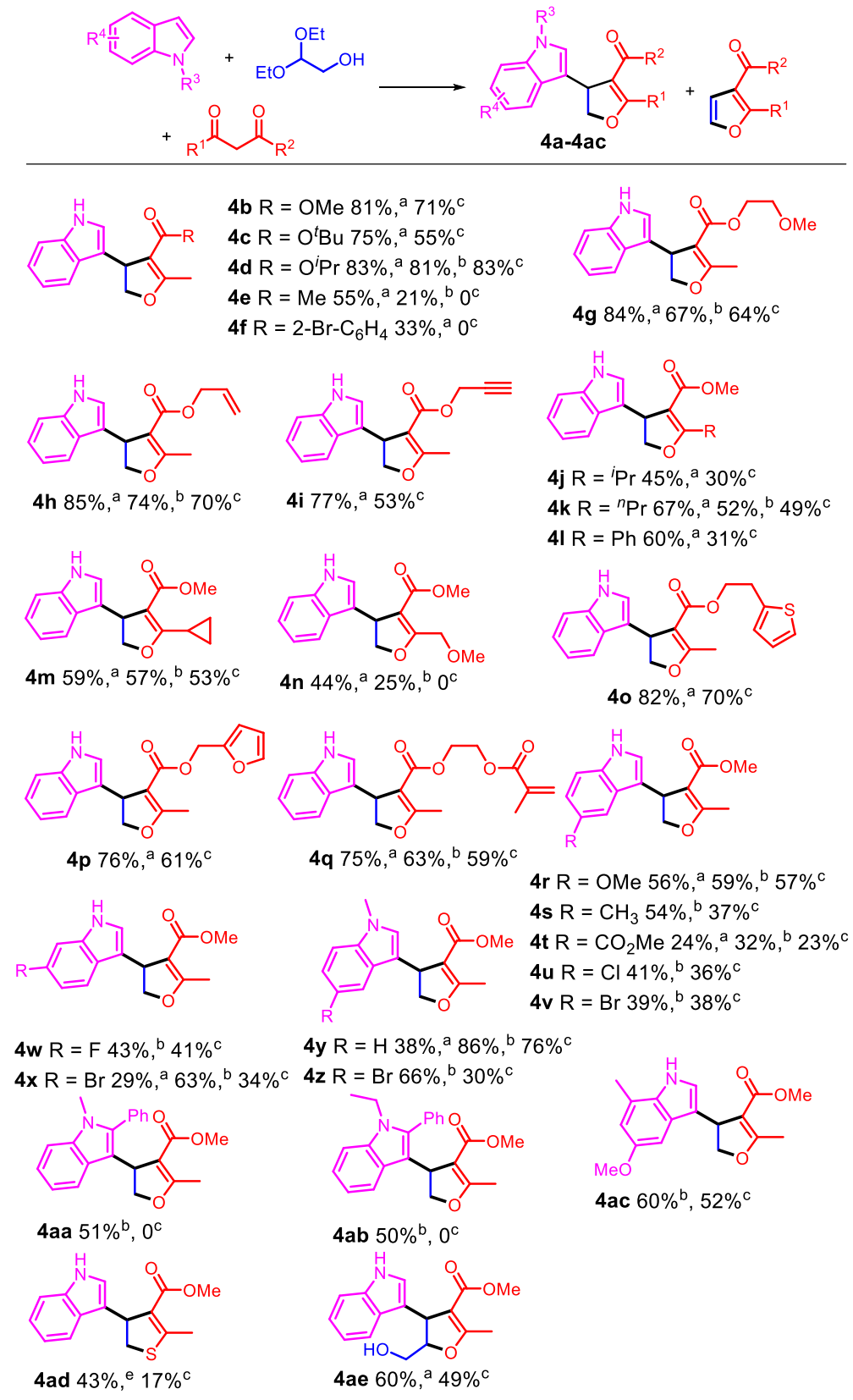

a: $1 \mathbf{a}(0.4 \mathrm{mmol}), \mathbf{2 a}(0.4 \mathrm{mmol}), 3 \mathbf{a}(0.2 \mathrm{mmol})$, method A: Sc(OTf) 3 catalyst $(5 \mathrm{~mol} \%)$, r.t., nitromethane $(1.0 \mathrm{~mL}), 1$ h. ${ }^{\text {b: }} \mathbf{1 a}(0.4 \mathrm{mmol}), \mathbf{2 a}(0.4 \mathrm{mmol}), \mathbf{3 a}(0.2 \mathrm{mmol})$, method B: $\mathrm{Ni}\left(\mathrm{ClO}_{4}\right)_{2} \cdot 6 \mathrm{H}_{2} \mathrm{O}$ catalyst $(20 \mathrm{~mol} \%), 80{ }^{\circ} \mathrm{C}$, acetonitrile $(1.0 \mathrm{~mL}), 6$ h. ${ }^{\text {c: }} \mathbf{1 a}(0.4$ mmol), 2a (0.4 mmol), 3a (0.2 mmol), method C: $\mathrm{FeCl}_{3} \cdot 6 \mathrm{H}_{2} \mathrm{O} / \mathrm{meg}$ lumine- $\mathrm{H}_{2} \mathrm{O}$ (15 mol\%), $80{ }^{\circ} \mathrm{C}, 10 \mathrm{~h}^{\mathrm{e}}{ }^{\mathrm{e}}: \mathbf{1 a}(0.2 \mathrm{mmol}), \mathbf{2 a}(0.4 \mathrm{mmol}), \mathbf{3 a}(0.2 \mathrm{mmol})$, method $\mathbf{C}: \mathrm{MnBr}_{2}$ catalyst $(20 \mathrm{~mol} \%), 60{ }^{\circ} \mathrm{C}$, acetonitrile $(1.0 \mathrm{~mL}), 12 \mathrm{~h}$.

Scheme 1. Substrate scope of three-component reaction of indoles, glycolaldehyde acetal and 1,3-dicarbonyl compounds. 


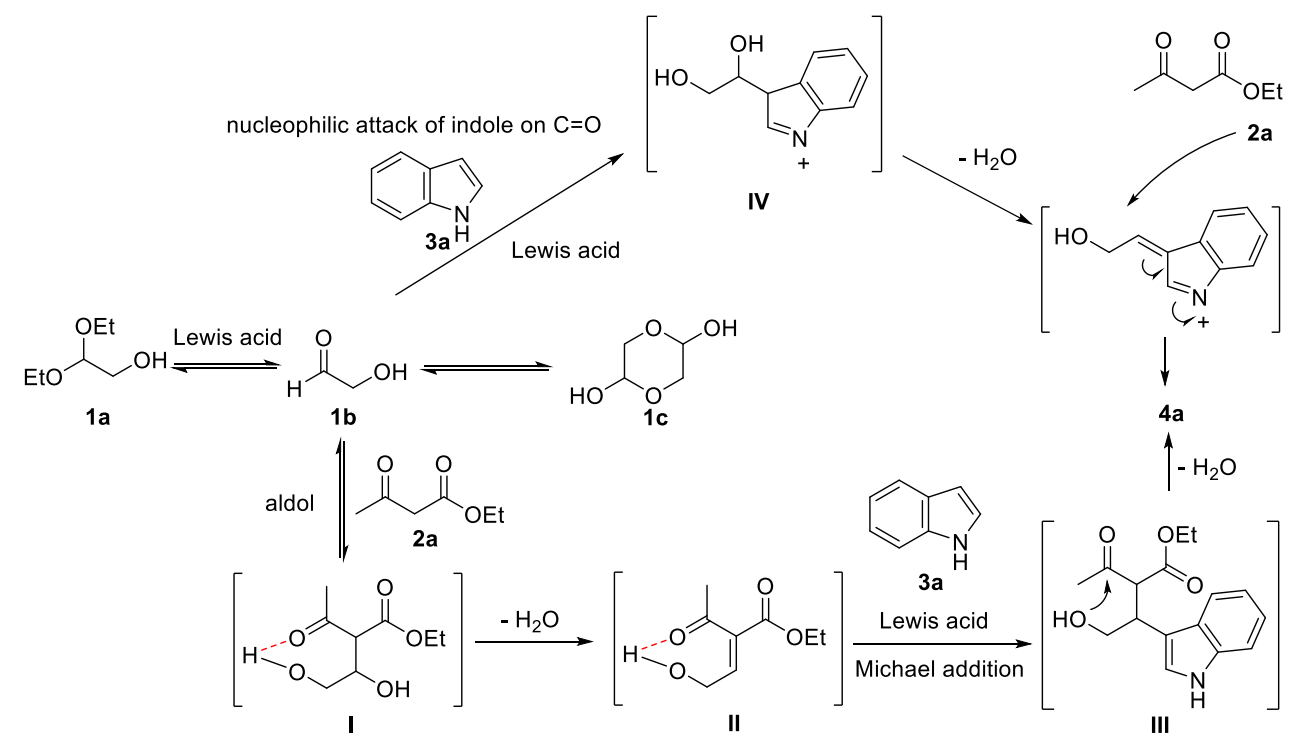

Scheme 2. Proposed mechanism of a three-component reaction.

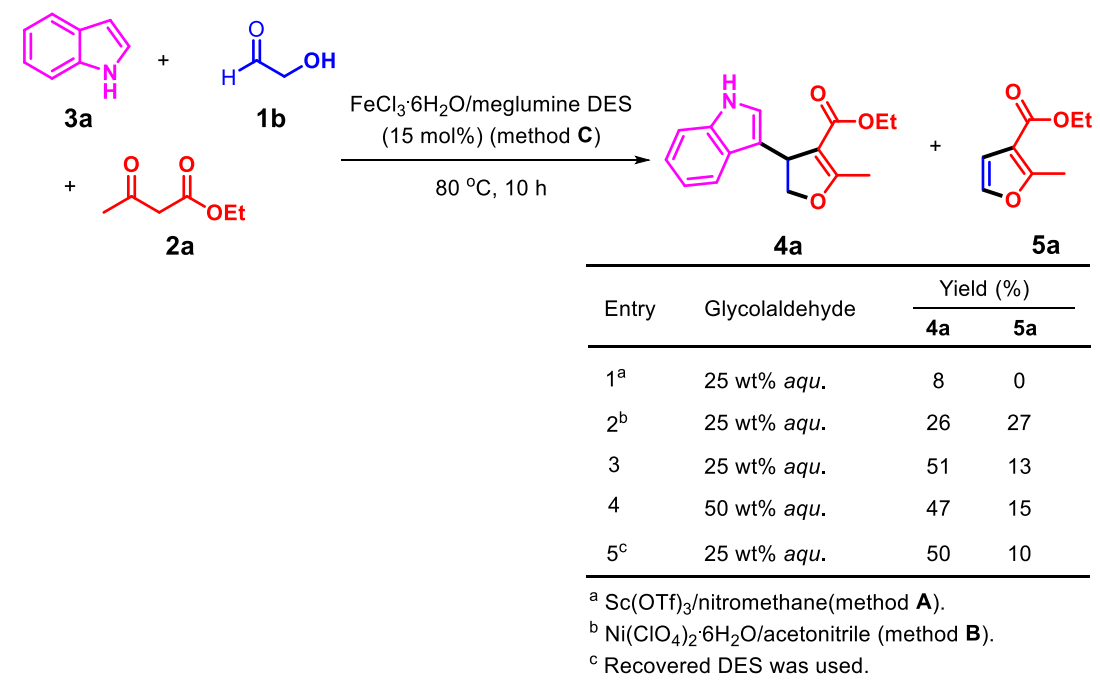

Scheme 3. A three-component reaction of using bio-based glycolaldehyde aqueous solution in the $\mathrm{FeCl}_{3} \cdot 6 \mathrm{H}_{2} \mathrm{O} /$ meglumine DES. 